\title{
The Partnership between the Chinese Government and Hong Kong's Capitalist Class: Implications for HKSAR Governance, 1997-2012
}

\author{
Brian C.H. Fong
}

\begin{abstract}
Existing literature has long recognized that a partnership has been forged between the PRC government and Hong Kong's capitalist class. However, the implications of such a partnership for HKSAR governance have yet to be thoroughly explored. By examining the formation of this partnership and its consolidation after 1997, this article argues that the business sector's direct access to the sovereign state has fundamentally changed the dynamics of state-business relations in the HKSAR. As a consequence of the partnership between Beijing and the business sector, business elites have taken their concerns straight to the mainland authorities whenever they see their interests affected by the post-colonial state. This kind of circumvention has become a part of post-1997 politics, undermining the relative autonomy of the post-colonial state and resulting in growing cleavages within the statebusiness alliance during the first 15 years of the HKSAR. Whether and how such a partnership will evolve in the aftermath of the 2012 chief executive election remains to be seen.
\end{abstract}

Keywords: Chinese government; state-business relations; governance; Hong Kong

Existing literature has long recognized that a close partnership has been forged between the PRC government and Hong Kong's capitalist class since the transition period of the $1980 \mathrm{~s}-90 \mathrm{~s} .{ }^{1}$ However, the implications of such a partnership for governance of the Hong Kong Special Administrative Region (HKSAR) have yet to be thoroughly explored. By examining the formation of this partnership and its consolidation after 1997, this article argues that the business sector's direct access to the sovereign state has fundamentally changed the dynamics of state-business relations in the HKSAR. Whenever business elites see their interests affected by

\footnotetext{
* Hong Kong Institute of Education. Email: chfong@ied.edu.hk.

1 Goodstadt 2000 and So 1999.
} 
affairs in Hong Kong, they bypass the HKSAR government and go straight to Beijing where their concerns will receive a sympathetic hearing. This kind of circumvention has become a part of post-1997 politics, undermining the relative autonomy of the post-colonial state and resulting in growing cleavages within the state-business alliance during the first 15 years of the HKSAR era.

This article is organized into four sections. It begins with a review of the origins of the partnership between Beijing and the business sector in Hong Kong. It then goes on to discuss the consolidation of this partnership since 1997 through institutionalized communication channels, the Liaison Office's united front work and mainland-Hong Kong economic integration. The third section examines how privileged access to Beijing has equipped Hong Kong's business elites with power leverages vis-à-vis the post-colonial Hong Kong state and how this has eroded HKSAR autonomy. Finally, the article discusses prospects for the partnership in the wake of the 2012 chief executive election.

\section{The Politics of Transition and the Origins of the Partnership}

The partnership between Beijing and Hong Kong's capitalists can be traced back to the Sino-British negotiations of 1982-84. ${ }^{2}$ According to the principles of "one country, two systems" and "Hong Kong people ruling Hong Kong," the HKSAR government would be made up of local Hong Kong people. In other words, the Chinese government would not have any official presence in the future HKSAR government and would have to groom reliable local agents to exercise governing power after 1997. ${ }^{3}$ Thus, the key question for Beijing leaders at that time was who could be entrusted to govern the HKSAR? Clearly, it was Beijing's intention that Hong Kong's capitalists would make up the majority of the future HKSAR political establishment and extend the colonial state-business governing coalition. ${ }^{4}$ According to Xu Jiatun 许家屯, director of Xinhua News Agency Hong Kong branch (Xinhua Hong Kong) from 1983 to 1989, Beijing was of the view that:

To implement the principle of "Hong Kong people ruling Hong Kong," the future HKSAR government shall be mainly made up of the local capitalist class with the participation of the working class. It shall be a cross-class alliance, but the capitalist class should form the core of the whole alliance [author's translation]. ${ }^{5}$

Beijing's definition of "Hong Kong people ruling Hong Kong" was about building a governing coalition between the future HKSAR government and the business sector. The reason why Beijing chose to partner itself with local capitalists is revealed through a closer examination of the politics of the transition period, which shows the convergence of the interests of Beijing and the business sector.

2 For an account of the Sino-British negotiations, see Tsang 1997, 81-110.

3 Ma 2007, 34.

4 From the founding of the colony, the colonial administration maintained a collaborative alliance with the British and local Chinese capitalists. For details, see Rear 1971; Ngo 2000a.

$5 \mathrm{Xu} 1993,141-42$. 
Beijing knew that it was essential to gain the support of the business sector in order to maintain the stability of Hong Kong's capitalist system. ${ }^{6}$ In the eyes of the PRC's leaders, Hong Kong's capitalism is not just a system of competitive markets, but is actually a political economy dominated by big capitalists. ${ }^{7}$ The strategic importance of the business sector to the stability of Hong Kong's economy and society was demonstrated by the economic turbulence caused by the outflows of capital, led by major British hongs such as the Jardine Group and HSBC, ${ }^{8}$ during the transition period. Beijing believed that the future stability of Hong Kong was dependent upon maintaining the confidence of investors and that it was critical to co-opt local Chinese capitalists to fill the vacuum left by the exodus of British capital. ${ }^{9}$ When Xu Jiatun was appointed as head of Xinhua Hong Kong in 1983, he quickly found that his chief tasks would be, "delaying the outflow of British capital, stabilizing the local Chinese capital, solidifying Taiwan capital, attracting foreign capital and strengthening mainland capital." 10

Second, Beijing viewed securing the support of business elites as strategically important to China's own economic reforms. Hong Kong's global business networks and its status as an international financial centre were invaluable assets for China in its efforts towards building a market economy. ${ }^{11}$ More importantly, Hong Kong's business people were the major investors in China, providing almost two-thirds of foreign domestic investment during the 1980s and 1990s. As such, securing the support of local capitalists in the resumption of Chinese sovereignty over Hong Kong was not only an important way to maintain stability in Hong Kong, it was also of paramount importance to Beijing's own economic modernization. ${ }^{12}$

Third, Beijing saw the business sector as a valuable ally in fending off challenges by Hong Kong's democrats. The PRC government was afraid that the democratization process started in the 1980s would gradually lead to the rise of a highly autonomous, if not independent, government in Hong Kong that would be beyond its control. ${ }^{13}$ The active participation of democrats in the 1989 Tiananmen movement further alarmed the mainland authorities, who were concerned that rapid democratization in Hong Kong would not be conducive to their own regime interests. Beijing wished to consign the implementation of universal suffrage in Hong Kong to a distant future date, and saw the politically conservative business sector as a reliable partner in the fight against democrat challenges. ${ }^{14}$

6 King 1991.

7 Goodstadt 2000

8 For an account of the exodus of British capital, see Feng 1996, 289-311 and 312-339.

9 Yep 2009.

$10 \mathrm{Xu} 1993$.

11 Yep 2007.

12 Goodstadt 2000

13 So 1999.

14 Yep 2009. 
It is also important to look at why Hong Kong's capitalist class, and in particular the local Chinese business community, made the collective decision to abandon their previous partnership with the colonial Hong Kong state and turn to the new governing coalition engineered by Beijing. In short, the shift was actually a calculated collective response made in a time of "contentious politics" 15 as a means of overcoming the common challenges presented at that time. In this connection, the most important challenge faced by the business elites was the reconstitution of Hong Kong's political order in the transition period. In the colonial era, the collaborative alliance between the colonial state and the business sector had allowed local capitalists to enjoy the privileges of a pro-business policy environment, including low taxation, minimum welfare provision and few government regulations. However, the impending change in sovereignty implied that the colonial political order was going to be reconfigured. This gave Hong Kong's business leaders a strong sense of insecurity, and led them to explore new approaches to maintaining their privileged position in post-handover Hong Kong. ${ }^{16}$

The rise of the democrats during the transition period also fuelled the business sector's sense of uncertainty. For the local capitalists, the democrats' demand for constitutional reform was an unprecedented challenge to their class interests. Business elites were afraid that their privileged position in Hong Kong would be undermined as a result of democratization, and electoral politics would bring about stronger trade unions, higher taxes and more government regulations. ${ }^{17}$ In fact, the business sector's worries were not without grounds. From the 1980s onwards, the democrats had begun to win landslide election victories by promoting a pro-welfare and pro-grassroots agenda. The business community thought that it could rely on Beijing to resist this trend towards democratization. ${ }^{18}$

During this time of contentious politics, the business elites, and in particular the local Chinese capitalists, believed it was necessary to protect their vested interests by seeking political patronage from the incoming sovereign state. ${ }^{19}$ Clearly, the business community's interests coincided with those of Beijing, and enabled the smooth formation of a partnership. On the one hand, this alliance allowed Beijing to secure a reliable coalition partner with whom it could contain the waves of democratization and safeguard Hong Kong's capitalist system, while on the other hand it provided the business sector with a platform to extend its influence over the territory. ${ }^{20}$

15 Comparative studies on state building indicate that political elites are more inclined to take collective action to pursue broader class interests when they are facing common political challenges in times of "contentious politics." For details, see Slater 2010.

16 Ngo 2000a.

17 So 1999.

18 Loh 2010, 163

19 For example, Xu Jiatun mentioned in his memoirs that local capitalists like Pao Yue-kong, Li Ka-shing, Kwok Tak-Seng, Run Run Shaw, Fok Ying-tung and Cha Chi-min had maintained close ties with him throughout the 1980s and they frequently sought Xu's opinion about China's policy towards Hong Kong. See Xu 1993, 129.

20 Goodstadt 2009, preface ix. 
The formation of this partnership was evident by Beijing's co-option of business elites into its united front during the transition period. ${ }^{21}$ Business tycoons were appointed to the various bodies responsible for administering the transition of sovereignty, including the Basic Law Drafting Committee, the Basic Law Consultative Committee, the Hong Kong Affairs Advisers, the Preliminary Working Committee and the HKSAR Preparatory Committee. Business leaders were also co-opted by Beijing as representatives of Hong Kong's compatriots to the National People's Congress (NPC) and the National Committee of the Chinese People's Political Consultative Conference (CPPCC). Indeed, the transition period saw the replacement of the old political alliance between the colonial state and Hong Kong's capitalist class with a new "China-centered state-business alliance."22

\section{The Consolidation of the Partnership Post-1997: the Business Sector's Direct Access to the Sovereign State}

Since the handover, Hong Kong's capitalists have consolidated their privileged access to the new sovereign state by virtue of their over-representation among the Hong Kong delegations to the NPC and CPPCC, their close relationship with the Liaison Office and their intricate business networks with the mainland authorities.

\section{The business sector's institutionalized access to the sovereign state}

Since the 1980s, Beijing has used the NPC and CPPCC as the principal platforms for incorporating Hong Kong's capitalists and business elites. This trend continued after 1997. ${ }^{23}$ Empirical research on the occupational backgrounds of all Hong Kong NPC and CPPCC delegates after 1997 shows that the business sector was consistently the dominant player within Beijing's united front (Table 1 and 2). Within the NPC delegations, business people occupied an average of 43.7 per cent of the total number of seats, while representatives of the business sector within the CPPCC delegations held 70.8 per cent of seats. Hong Kong's delegations included tycoons like Chan Yau-hing 陳有慶 and Tsang Hin-chi 曾憲梓 (NPC), and Li Tzar-kuoi 李澤鉅, Cheng Kar-shun 鄭家純, Kwok Ping-sheung 郭炳湘, Lo Hong-sui 羅康瑞, Fung Kwok-king 馮國經 and Wu Ying-sheung 胡應湘 (CPPCC), covering almost all the big business families in Hong Kong.

The business sector's dominance over the Hong Kong NPC and CPPCC delegations not only gives local capitalists political prestige, but it also provides them with an unprecedented institutionalized channel through which to gain direct

21 For empirical studies on the Chinese government's political co-option in the transition period, see Cheung and Wong 2004.

22 So 1999.

23 Since 1997, Hong Kong deputies to the NPC have been elected locally through an election conference, while the Hong Kong members to the CPPCC are "invited" by Beijing authorities. In practice, the local NPC and CPPCC delegates are handpicked by Beijing through the Liaison Office. 
Table 1: Background Analysis of Hong Kong Deputies in the NPC (1998-2012)

\begin{tabular}{|c|c|c|c|c|c|c|c|c|}
\hline \multirow[t]{2}{*}{$\begin{array}{l}\text { Occupational } \\
\text { background }\end{array}$} & \multicolumn{2}{|c|}{$\begin{array}{c}\text { 9th NPC } \\
(1998-2002)\end{array}$} & \multicolumn{2}{|c|}{$\begin{array}{c}\text { 10th NPC } \\
(2003-2007)\end{array}$} & \multicolumn{2}{|c|}{$\begin{array}{c}\text { 11th NPC } \\
(2008-2012)\end{array}$} & \multicolumn{2}{|c|}{ Total } \\
\hline & No. & $\%$ & No. & $\%$ & No. & $\%$ & No. & $\%$ \\
\hline Politician & 1 & 3 & 1 & 2.9 & 0 & 0 & 2 & 1.9 \\
\hline Business & 14 & 42.4 & 15 & 42.9 & 16 & 45.7 & 45 & 43.7 \\
\hline Professional & 3 & 9.1 & 3 & 8.6 & 8 & 22.9 & 14 & 13.6 \\
\hline Social services & 10 & 30.3 & 10 & 28.6 & 8 & 22.9 & 28 & 27.2 \\
\hline Labour & 2 & 6.1 & 3 & 8.6 & 1 & 2.9 & 6 & 5.8 \\
\hline Culture \& media & 1 & 3 & 1 & 2.9 & 0 & 0 & 2 & 1.9 \\
\hline Others & 2 & 6.1 & 2 & 5.7 & 2 & 5.7 & 6 & 5.8 \\
\hline Total* & 33 & 100 & 35 & 100 & 35 & 100 & 103 & 100 \\
\hline
\end{tabular}

Source:

Author's own research based on the information available on the official website of the NPC and CPPCC sessions, http:/l 2011 lianghui.people.com.cn.

Notes:

"Politician" refers to full-time legislative councillors and district councillors; "Business" refers to chairmen, directors, executives and managers from commercial corporations; "Professional" refers to professionals from legal, accounting, architecture, surveying, planning, engineering, medical and health sectors; "Social services" refers to practitioners from education, community and social services, and religious sectors; "Labour" refers to trade unionists; "Culture \& media" refers to practitioners from the arts, culture, media and publishing sectors. *In each NPC delegation, there are a few "Chinese members" who are mainland officials stationed in the HKSAR, including officials from the Central Liaison Office, Chinese People's Liberation Army and the Office of the Commissioner of the Ministry of Foreign Affairs. These Chinese members have been excluded in the above table.

access to Beijing's top leaders. In the first quarter of every year, the annual full sessions of the NPC and the CPPCC meet in Beijing, after which all Hong Kong delegates continue to stay there for around two weeks to deliberate on national-level affairs in sessions known as lianghui 两会. The lianghui provides

\section{Table 2: Background Analysis of Hong Kong Members of the National Committee of the CPPCC (1998-2012)}

\begin{tabular}{|c|c|c|c|c|c|c|c|c|}
\hline \multirow[t]{2}{*}{$\begin{array}{l}\text { Occupational } \\
\text { background }\end{array}$} & \multicolumn{2}{|c|}{$\begin{array}{l}\text { 9th CPPCC } \\
(1998-2002)\end{array}$} & \multicolumn{2}{|c|}{$\begin{array}{c}\text { 10th CPPCC } \\
(2003-2007)\end{array}$} & \multicolumn{2}{|c|}{$\begin{array}{c}\text { 11th CPPCC } \\
(2008-2012)\end{array}$} & \multicolumn{2}{|c|}{ Total } \\
\hline & No. & $\%$ & No. & $\%$ & No. & $\%$ & No. & $\%$ \\
\hline Politician & 1 & 0.9 & 1 & 0.8 & 1 & 0.8 & 3 & 0.8 \\
\hline Business & 79 & 69.9 & 80 & 67.8 & 91 & 74.6 & 250 & 70.8 \\
\hline Profession & 7 & 6.2 & 11 & 9.3 & 7 & 5.7 & 25 & 7.1 \\
\hline Social services & 11 & 9.7 & 12 & 10.2 & 8 & 6.6 & 31 & 8.8 \\
\hline Labour & 3 & 2.7 & 2 & 1.7 & 2 & 1.6 & 7 & 2 \\
\hline Culture \& media & 10 & 8.8 & 7 & 5.9 & 5 & 4.1 & 22 & 6.2 \\
\hline Others & 2 & 1.8 & 5 & 4.2 & 8 & 6.6 & 15 & 4.2 \\
\hline Total* & 113 & 100 & 118 & 100 & 122 & 100 & 353 & 100 \\
\hline
\end{tabular}

Source:

Author's own research based on the information available on the official website of the NPC and CPPCC sessions, http:/l 2011 lianghui.people.com.cn.

Notes:

See notes for Table 1. *In each CPPCC delegation, there are a few "Chinese members" who are mainland officials stationed in the HKSAR, including officials from the Central Liaison Office, Chinese People's Liberation Army and the Office of the Commissioner of the Ministry of Foreign Affairs. These Chinese members have been excluded in the above table. 
a regular and direct communication channel through which Hong Kong's business elites can air their views on Hong Kong's affairs to Beijing officials. The NPC and CPPCC delegations also meet top state leaders at this time. ${ }^{24}$

\section{Political co-optation of the business elites through the united front work} of the Liaison Office

The consolidation of the partnership between Beijing and the Hong Kong's capitalist class after 1997 is also evident in the united front work conducted by the local agent of the sovereign state - the Liaison Office. During the colonial era, the British government in London did not attempt to govern Hong Kong directly. ${ }^{25}$ However, the Chinese government has put in place the machinery to manage local affairs in the HKSAR. Under the hierarchical structure of the Chinese Communist Party (CCP), the Central Leading Group on Hong KongMacau Affairs is the top-level task force responsible for overseeing Hong Kong affairs. Currently headed by Politburo Standing Committee member, Zhang Dejiang 张得江, the Central Leading Group is comprised of officials from relevant departments like the Ministry of Foreign Affairs and United Front Work Department. ${ }^{26}$ It is supported by four major units, namely the Hong Kong and Macau Affairs Office, the Liaison Office, the Office of the Commissioner of the Ministry of Foreign Affairs, and the People's Liberation Army Hong Kong Garrison. ${ }^{27}$

In this regard, the role of the Liaison Office is of particular importance. The Liaison Office, known as Xinhua Hong Kong before January 2000, is the official representative organization of the Chinese government in the territory and it is also where the CCP's Hong Kong and Macau Work Committee (HKMWC) is located. As the local agent of the sovereign state since 1997, the Liaison Office oversees an extensive network of "leftist organizations" such as commercial organizations (e.g. banks, department stores and tourist agencies), educational and cultural organizations (e.g. schools, newspapers and bookstores) and mass organizations (e.g. labour unions, district organizations and organizations for the elderly, youth and women). ${ }^{28}$

The principal function of the HKMWC is to conduct united front work in Hong Kong. In the construction of the united front, the business sector is always the principal target of co-option. Since the 1980s when it was the Xinhua Hong Kong headed by Xu Jiatun, the HKMWC has had a political co-option

24 For example, during the 2011 lianghui, arrangements were made for the Hong Kong delegations to have private meetings with the then vice-president, Xi Jinping, and director of the Hong Kong and Macau Affairs Office, Wang Guangya.

25 Miners 1987, 38.

26 Yep 2010.

27 Loh 2010, 201-06.

28 Ibid., 30. 
mechanism that focuses on drawing the business sector over to the side of Beijing, and this political strategy continues to direct its united front work today. ${ }^{29}$

The membership lists of the "Presidium of the preparatory committee of Hong Kong compatriots in celebration of the founding anniversary of the People's Republic of China” (guoqing chouweihui 国庆筹委会) demonstrate how extensively united front work is linked to the business sector. These preparatory committees are organized annually by the Liaison Office to coordinate national day celebration activities. Empirical research into the occupational backgrounds of the members shows that the business sector consistently made up the single largest group in the Liaison Office's united front, taking up, on average, 58.1 per cent of seats from 1998 to 2011 (Table 3). A closer examination of the membership lists reveals that big capitalists are regular members. Taking the 2011 Preparatory Committee as an example, members included big capitalists like $\mathrm{Li} \mathrm{Ka}$-shing 李嘉誠, Kwok Ping-sheung 郭炳湘, Lee Shau-kee 李兆基 and Cheng Yu-tung 鄭裕泮. Leaders of major business associations were also co-opted as regular members, including Wu Ting-yuk 胡定旭 (chairman of the Hong Kong General Chamber of Commerce), Choi Koon-shum 蔡冠深 (chairman of the Chinese General Chamber of Commerce), Wong Yau-ka 黃友嘉 (president of the Chinese Manufacturers' Association of Hong Kong) and Zhong Zhi-ping 鍾志平 (chairman of the Federation of Hong Kong Industries). While it is difficult to trace the behind-the-scenes united front work done by the Liaison Office, this finding provides insightful evidence about the close relationship between the business sector and the local agent of the sovereign state after 1997.

The business sector's increased economic links with the mainland authorities: mainland-Hong Kong economic integration and its political implications

The partnership between Beijing and Hong Kong's capitalists after 1997 is also the result of macro-economic changes across the boundaries. In the 1980s when Beijing initiated economic reforms, Hong Kong manufacturers relocated their factories to the mainland and Hong Kong's economy began to integrate with China. ${ }^{30}$ This process of economic integration accelerated in the 1990s owing to increased cross-border investments: Hong Kong investments in the mainland diversified from labour-intensive manufacturing industries into other sectors like real estate and infrastructure, while Chinese firms increased their investments in various sectors of Hong Kong's economy. The signing of the Closer Economic Partnership Agreement (CEPA) in 2003 further stimulated mainland-Hong Kong economic integration. ${ }^{31}$ The CEPA provided Hong Kong's businesses with greater access to China's market and also allowed mainland 
Table 3: Background Analysis of Members of the Presidium of the Preparatory Committee of Hong Kong Compatriots in Celebration of the Founding Anniversary of the People's Republic of China (1998-2011)

\begin{tabular}{|c|c|c|c|c|c|c|c|c|c|c|c|c|c|c|c|c|c|c|c|c|c|c|c|c|c|c|c|c|c|c|}
\hline \multirow[t]{2}{*}{ Occupation } & \multicolumn{2}{|c|}{1998} & \multicolumn{2}{|c|}{1999} & \multicolumn{2}{|c|}{2000} & \multicolumn{2}{|c|}{2001} & \multicolumn{2}{|c|}{2002} & \multicolumn{2}{|c|}{2003} & \multicolumn{2}{|c|}{2004} & \multicolumn{2}{|c|}{2005} & \multicolumn{2}{|c|}{2006} & \multicolumn{2}{|c|}{2007} & \multicolumn{2}{|c|}{2008} & \multicolumn{2}{|c|}{2009} & \multicolumn{2}{|c|}{2010} & \multicolumn{2}{|c|}{2011} & \multicolumn{2}{|c|}{ Total } \\
\hline & No. & $\%$ & No. & $\%$ & No. & $\%$ & No. & $\%$ & No. & $\%$ & No. & $\%$ & No. & $\%$ & No. & $\%$ & No. & $\%$ & No. & $\%$ & No. & $\%$ & No. & $\%$ & No. & $\%$ & No. & $\%$ & No. & $\%$ \\
\hline Government & 13 & 9.9 & 12 & 8.2 & 15 & 10.1 & 16 & 10.7 & 15 & 10 & 15 & 9.9 & 15 & 9.9 & 17 & 11.3 & 16 & 10.1 & 13 & 8.6 & 10 & 6.5 & 11 & 7.1 & 10 & 6.3 & 13 & 8.3 & 191 & 9 \\
\hline Politician & 3 & 2.3 & 3 & 2 & 3 & 2 & 3 & 2 & 3 & 2 & 3 & 2 & 3 & 2 & 3 & 2 & 3 & 1.9 & 3 & 2.0 & 3 & 1.9 & 3 & 1.9 & 2 & 1.3 & 3 & 1.9 & 41 & 1.9 \\
\hline Business & 79 & 60.3 & 87 & 59.2 & 82 & 55.4 & 85 & 56.7 & 84 & 56 & 89 & 58.9 & 90 & 59.6 & 90 & 59.6 & 92 & 58.2 & 90 & 59.6 & 90 & 58.1 & 91 & 58.3 & 93 & 58.1 & 86 & 55.1 & 1,228 & 58.1 \\
\hline Professional & 5 & 3.8 & 6 & 4.1 & 7 & 4.7 & 8 & 5.3 & 8 & 5.3 & 8 & 5.3 & 8 & 5.3 & 8 & 5.3 & 9 & 5.7 & 7 & 4.6 & 6 & 3.9 & 6 & 3.8 & 7 & 4.4 & 8 & 5.1 & 101 & 4.8 \\
\hline Social services & 15 & 11.5 & 16 & 10.9 & 16 & 10.8 & 17 & 11.3 & 16 & 10.7 & 14 & 9.3 & 15 & 9.9 & 15 & 9.9 & 20 & 12.7 & 21 & 13.9 & 24 & 15.5 & 25 & 16 & 26 & 16.3 & 25 & 16 & 265 & 12.5 \\
\hline Labour & 4 & 3.1 & 5 & 3.4 & 6 & 4.1 & 5 & 3.3 & 6 & 4 & 6 & 4 & 6 & 4 & 6 & 4 & 6 & 3.8 & 5 & 3.3 & 5 & 3.2 & 5 & 3.2 & 5 & 3.1 & 5 & 3.2 & 75 & 3.5 \\
\hline Culture \& media & 10 & 7.6 & 16 & 10.9 & 16 & 10.8 & 15 & 10 & 16 & 10.7 & 13 & 8.6 & 13 & 8.6 & 11 & 7.3 & 11 & 7 & 11 & 7.3 & 11 & 7.1 & 11 & 7.1 & 11 & 6.9 & 14 & 9 & 179 & 8.5 \\
\hline Others & 2 & 1.5 & 2 & 1.4 & 3 & 2 & 1 & 0.7 & 2 & 1.3 & 3 & 2 & 1 & 0.7 & 1 & 0.7 & 1 & 0.6 & 1 & 0.7 & 6 & 3.9 & 4 & 2.6 & 6 & 3.8 & 2 & 1.3 & 35 & 1.7 \\
\hline Total* & 131 & 100 & 147 & 100 & 148 & 100 & 150 & 100 & 150 & 100 & 151 & 100 & 151 & 100 & 151 & 100 & 158 & 100 & 151 & 100 & 155 & 100 & 156 & 100 & 160 & 100 & 156 & 100 & 2,115 & 100 \\
\hline
\end{tabular}

Source:

Author's own research based on the membership lists of the Presidium of Preparatory Committee for National Day Celebrations, available in Ta Kung Po and Wen Wei Po. Notes:

"Government" refers to political officials or civil servants of the HKSAR government; see notes for Table 1 for definitions of other categories. *There were a few "Chinese members" (i.e. mainland officials from central government offices in the HKSAR including the Liaison Office, Chinese People's Liberation Army in Hong Kong and the Office of the Commissioner of the Ministry of Foreign Affairs in Hong Kong) in each preparatory committee. These Chinese members have been excluded in the above table. 
Figure 1: Hong Kong's Total Trade with Mainland China

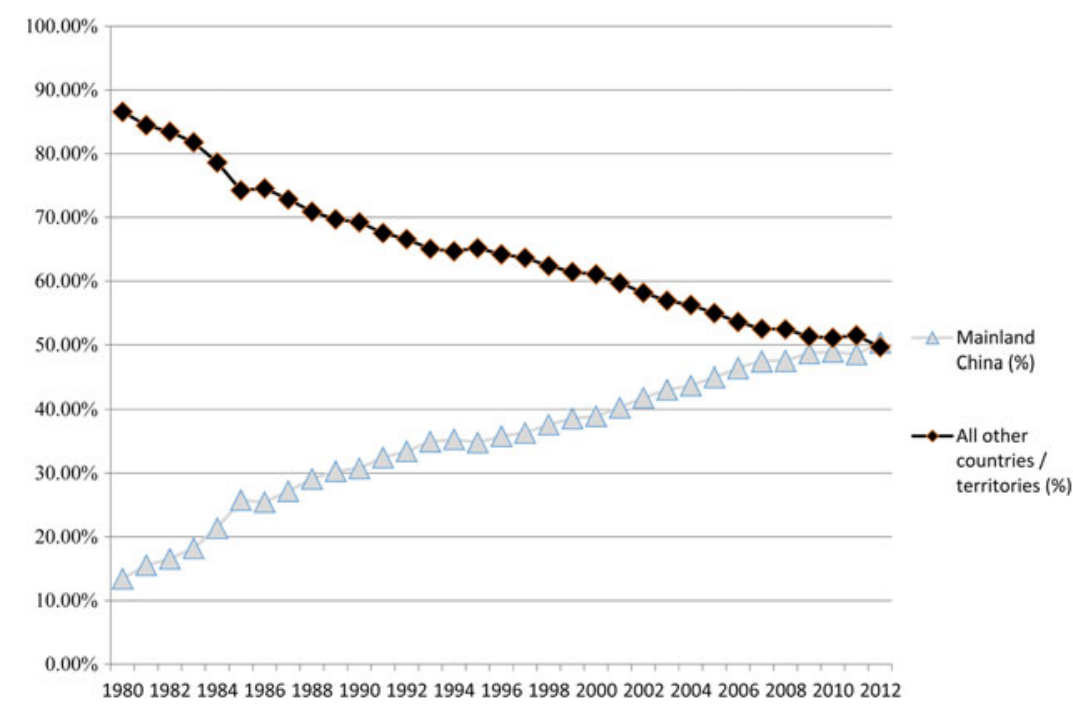

Source:

Adapted from the statistical tables available at the Census and Statistics Department's website at http:/www.censtatd.gov.hk.

Chinese firms to make better use of Hong Kong's financial and business services. ${ }^{32}$ The breadth and depth of mainland-Hong Kong economic integration are illustrated in Figures 1 to 4. As seen in Figures 1 and 2, Hong Kong's trade with the mainland accounts for nearly half of the territory's trade volumes, and the mainland has become the biggest investor in the territory. Figure 3 indicates that the mainland is the principal investment destination for Hong Kong firms ${ }^{33}$ and Figure 4 illustrates that major Hong Kong conglomerates have substantially increased their investments in the mainland over the past decade.

Mainland-Hong Kong economic integration has given Hong Kong's business elites increased privileged access to the mainland authorities. While the economic reforms implemented by the Chinese government over the past few decades have developed a robust private sector, the CCP has retained its control over many strategic economic sectors such as telecommunications and finance through state-owned enterprises, and various levels of governments have also set up their own companies. ${ }^{34}$ Provincial and municipal governments also have the power to approve investment projects initiated by "foreign capital," including capital from Hong Kong. ${ }^{35}$ Therefore, when Hong Kong's conglomerates expand

33 Excluding the British Virgin Islands, which are home to many of Hong Kong's offshore companies.

34 Dillion 2009, 43.

35 Ngo 2000b. 
Figure 2: Hong Kong's Inward Direct Investment by Major Recipient Country at Market Value (1998-2011)

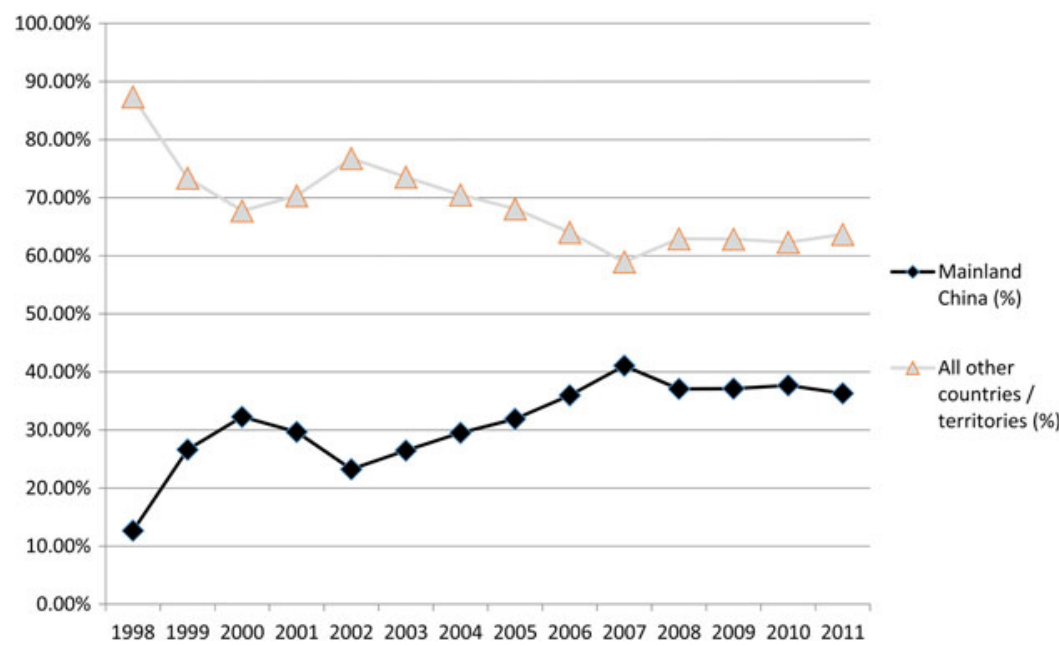

Source:

Adapted from the statistical tables available at the Census and Statistics Department's website at http://www.censtatd.gov.hk.

Figure 3: Hong Kong's Outward Direct Investment by Major Recipient Country at Market Value (1998-2011)

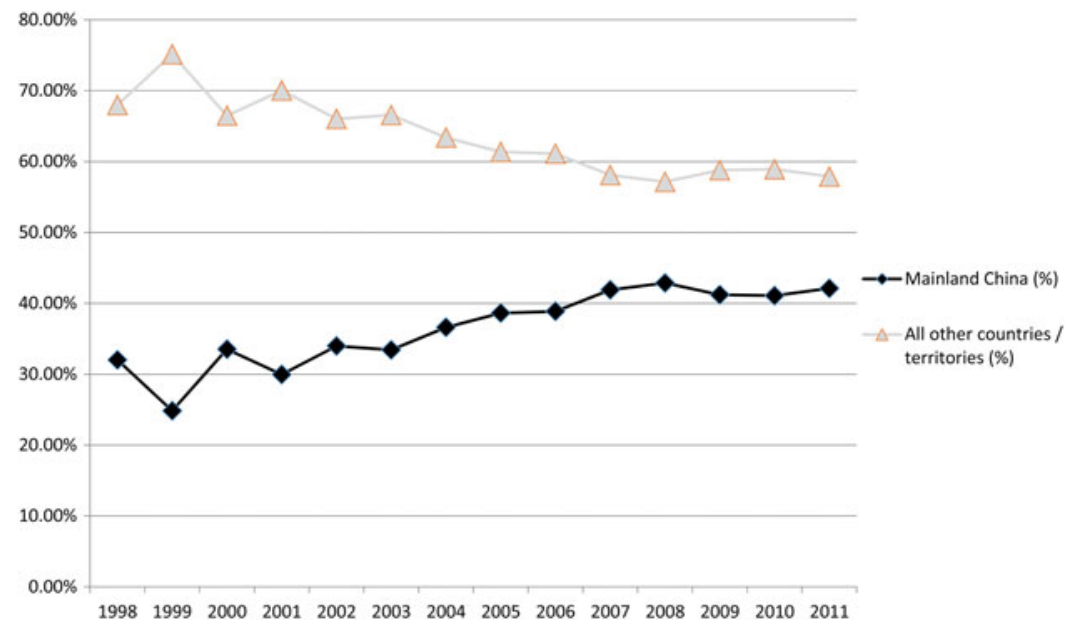

Source:

Adapted from the statistical tables available at the Census and Statistics Department's website at http://www.censtatd.gov.hk.

their investments in China, they often work closely with the central and provincial governments and their subsidiary companies, or actively pursue patronage from senior CCP leaders in order to overcome the various bureaucratic hurdles 


\section{Figure 4: Percentage of Assets Held by Hong Kong Conglomerates in the Mainland}

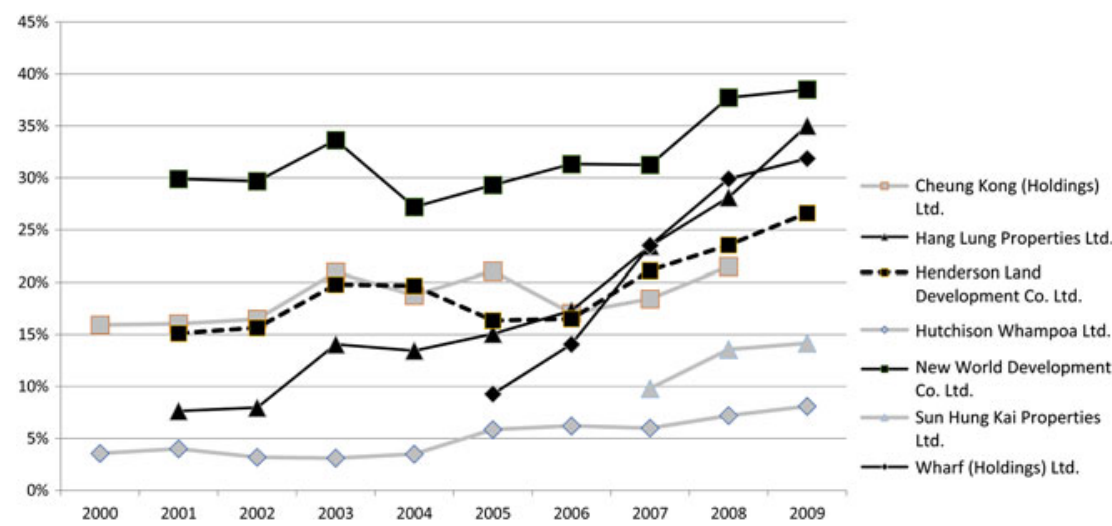

Note:

According to the "Hong Kong Financial Reporting Standard 8 - Operating Segments," listed companies are required to disclose and report segment information about the different types of products and services they produce and the different geographical areas in which they operate. Such a standard arises from the International Accounting Standards Board's consideration of the Financial Accounting Standards Board in the United States Statement No. 131 Disclosures about Segments of an Enterprise and Related Information issued in 1997 (Hong Kong Institute of Certified Public Accountants, 2009). Most of the major conglomerates in Hong Kong started reporting such geographical information in 2000, but on certain occasions some companies will choose not to disclose their geographical information if the total amount of their assets, revenues and profits outside Hong Kong are not material or significant. The author collected the geographical information of the chosen major conglomerates in Hong Kong when such information and data were available in their annual financial reports.

Source:

Author's own research based on the annual financial reports of the chosen companies.

when seeking approval for investment projects. ${ }^{36}$ At the same time, those subsidiaries owned by central and local governments will also cooperate with Hong Kong's capitalists when they set up their businesses in the HKSAR, and provincial and municipal officials are also eager to attract investment from Hong Kong. ${ }^{37}$ Thus, cross-border economic activities have allowed Hong Kong's capitalists to develop intricate business networks and close personal ties with mainland officials. ${ }^{38}$

36 For example, Li Ka-shing had fostered complex business connections with Deng Xiaoping's family by helping the Shougang Group to become one of the largest "red chip companies" on Hong Kong's stock market in the 1990s. In return, Li Ka-shing's guanxi with the Deng family helped him to expand his business empire in the mainland and also realize the controversial Oriental Plaza project in the prime areas of Beijing. See Ngo 2000b.

37 It is common for local Party officials to lead business delegations (zhao shang tuan) to Hong Kong in order to attract investment from Hong Kong's capitalists. For example, Xi Jinping, who served as Party secretary of Zhejiang province from 2002 to 2007, led a large-scale business delegation to Hong Kong in 2005 and held private meetings with local tycoons and leaders of major business associations. See "Xi Jinping shuai Zhe shang dao Gang mi shang ji” (Xi Jinping leads Zhejiang business delegation to Hong Kong), Wen Wei Po, 17 January 2005, A01.

38 For example, Zhang Gaoli, who was promoted to the Politburo Standing Committee at the 18th Party Congress in 2012, maintained close ties with Li Ka-shing throughout his career. Zhang developed his friendship with $\mathrm{Li}$ during his tenure as Party secretary of Shenzhen, and Li even visited Shenzhen to bid farewell to Zhang personally before he moved to Shandong in 2002. When Zhang led a business delegation to Hong Kong in 2002 in his capacity as governor of Shandong province, he was warmly 


\section{The Different Roles of Sovereign States in Governing Coalition-Building Pre- and Post-1997}

The Chinese government did not initiate the practice of governing Hong Kong through a state-business partnership, but rather inherited the situation from the colonial Hong Kong state. Prior to the handover, business elites had been extensively co-opted by the colonial state onto various advisory bodies. In the post-1997 era, the business sector continues to be the major coalition partner of the Hong Kong government and forms the single largest group on major advisory committees. ${ }^{39}$ On the surface, it appears that Hong Kong was, and continues to be, governed by a similar political alliance between the government and the business sector both before and after 1997. However, the different roles of the sovereign states imply that the internal dynamics of the governing coalitions are fundamentally different. Before 1997, London largely took a back seat and the colonial state, headed by the governor, was the ultimate power holder within the state-business alliance; after 1997, although the post-colonial state headed by the chief executive has continued to absorb business elites into its advisory machinery as in the colonial past, the new sovereign state - Beijing - has stepped in by co-opting the business sector on its own through the appointment of NPC and CPPCC delegates and the united front work of the Liaison Office.

\section{Relations between London and Hong Kong's capitalist class before 1997}

Comparatively speaking, prior to the handover, the sovereign state (London) kept a distance from Hong Kong's business sector, largely owing to several reasons. First, the two parties did not share common political or economic agendas, leaving little room for business elites to exert their influence by appealing to London for support. It was established practice by the British government to prevent the business sector from controlling the political agenda in the colony. Although the Hong Kong colony was established in order to facilitate British trade activities in the Far East, London could not afford to run the colony for the exclusive benefit of business interests at the expense of the local Chinese population. Thus, whenever the British capitalists sought to expand their influence by lobbying support in London, the British government usually chose not to entertain their requests and would join hands with the governor in resisting

footnote continued

welcomed by Li Ka-shing who openly pledged to increase his investments in Shandong. When Zhang became Party secretary of Tianjin in 2007, Li's companies also expanded their investments there. See "Zhang Gaoli zai Shen wu Li Ka-shing" (Zhang Gaoli meets Li Ka-shing in Shenzhen), Ta Kung Po, 13 December 2001, A04; "Chao Yan Lie ri qin Ying Zhang sheng zhang" (Li Ka-shing greets Zhang Gaoli under the burning sun), Wen Wei Po, 9 May 2002, B01; "Zhang Gaoli chang JinGang hezuo" (Zhang Gaoli advocates cooperation between Yianjin and Hong Kong), Hong Kong Economic Times, 19 September 2008, A38.

39 Cheung and Wong 2004. 
these pressures..$^{40}$ Economically, while Hong Kong was Britain's business centre in the Far East in the 19th century, the economic links between the business sector and London became less important after the Second World War. Following the dissolution of the British empire in the 1950s, the United Kingdom developed closer economic ties to the European Economic Community and the economic linkages between Hong Kong and London steadily weakened. ${ }^{41}$

Second, Hong Kong's capitalists never had institutionalized access to the British government. They were discouraged from appealing to the Colonial Office, and, indeed, the governor remained the only official channel of communication between Hong Kong and London. ${ }^{42}$ While there were certain occasions when the business sector had taken their complaints straight to the Colonial Office in London, these incidents were exceptional cases. ${ }^{43}$

Finally, London did not establish any local governing mechanisms in Hong Kong and relied on the governor to manage the day-to-day affairs in the territory. One notable feature of British policy on managing its colonial empire was the devolution of power to the local governors in administering the colonies, meaning that London took no great interest in the day-to-day affairs of a colony unless there was a major crisis. ${ }^{44}$ Thus, for most of the time, the colonial Hong Kong state maintained a great deal of political autonomy when managing the territory. ${ }^{45}$

To sum up, the lack of a common political and economic agenda, the absence of institutionalized communication channels, and the fact that there was no strong British government presence in Hong Kong, meant that the relationship between the business sector and the sovereign state remained distant during the colonial era, making it difficult for the business sector to exert its political influence by means of circumvention activities. ${ }^{46}$ This helped to sustain the relative autonomy of the colonial state in administering Hong Kong and upheld the authority of the governor as the ultimate holder of power in the territory.

\section{Relations between Hong Kong's capitalist class and Beijing after 1997}

The dynamics of state-business relations have changed fundamentally since 1997 owing to the fact that the business sector has now gained direct access to the sovereign state. Unlike London, Beijing has a direct stake in the governance of the HKSAR and increasingly adopts a more interventionist governing style. ${ }^{47}$ Beijing

40 Goodstadt 2009, 33.

41 Ibid., 53, 231.

42 Miners 1987, 38, 48.

43 Scott 1989, 249.

44 Lau 1994.

45 Miners 1998, 214.

46 Yep 2009.

47 Despite the one country, two systems framework enshrined in the Basic Law, Beijing considers it necessary, on top of the HKSAR government headed by the chief executive, to maintain its own political machinery in the territory so as to enforce the "one country" principle. The strategic considerations of Beijing were stated explicitly by the Liaison Office's head of research, Cao Erbao, in his controversial 
has actively been engaged in creating a state-business alliance and has seen the business sector as its principal target of co-option. The rules of engagement designed by Beijing to continue the state-business alliance after 1997 allow the business sector to establish direct access to the sovereign state and have significantly changed the rules of political behaviour in the HKSAR era.

The business sector's direct access to Beijing has meant that the nature and functioning of the state-business alliance is essentially different before and after 1997. In the colonial era, the business sector's restricted access to the sovereign state meant that governing coalition-building was basically a twoplayer game between the colonial Hong Kong state and the business sector, with the governor as the final arbitrator within the state-business alliance. It was difficult for business elites to challenge the governor's authority by making claims to London, thus enabling the colonial state to maintain a higher degree of autonomy vis-à-vis the business sector. However, after 1997, owing to the close partnership between business elites and the sovereign state, governing coalition-building has become a three-player game between the sovereign state, the post-colonial Hong Kong state and the business sector. Beijing's leaders, rather than the chief executive, have become the real power centre of the statebusiness alliance.

This important change in the nature of the state-business alliance has seriously eroded the autonomy of the post-colonial state and has brought about farreaching implications for HKSAR governance. As some neo-Marxists have pointed out, under a capitalist system the state must serve the interests of the bourgeoisie by facilitating capital accumulation on the one hand, but must also maintain a certain degree of autonomy from the capitalist class on the other. The significance of relative autonomy lies in its strategic importance in enabling the state to pursue a policy agenda broader than the interests of any particular interest group and achieve an appropriate balancing of different interests in society. ${ }^{48}$ In the colonial era, despite its political alliance with the big capitalists, the colonial state was able to maintain a considerable degree of relative autonomy vis-à-vis the business sector. The colonial state was quite effective in performing its role as an arbitrator of class interests and was able to mitigate social contradictions by pursuing policy reforms that were not welcome by the business elites. ${ }^{49}$ However, post-1997 developments have shown that the postcolonial state's impartiality has become increasingly untenable.

\footnotetext{
footnote continued
}

article in 2008. In this article, Cao provided an account of the operations of the mainland agencies in Hong Kong and argued that these agencies, and in particular the Central Liaison Office, should operate as the "second governing team" in parallel to the HKSAR government (the first governing team). See Cao 2008.

48 See Miliband 1969; Poulantzas 1978.

49 Scott 1989, 58-59. 
Since 1997, the business sector's increased access to the sovereign state has provided the local capitalists with unprecedented channels through which to wield influence over the post-colonial state. With Beijing, rather than the chief executive, as the de facto power centre of the state-business alliance since the handover, local capitalists can take their concerns directly to Beijing or the Liaison Office and thereby exert pressure on the HKSAR government if they see their interests affected by government policies. ${ }^{50}$ From this perspective, the partnership between Beijing and Hong Kong's capitalists has effectively changed the balance of power between the post-colonial state and the business sector: now local capitalists are able to use their privileged access to the sovereign state to challenge the governing authority of the chief executive and to bargain for policy concessions. The direct political consequence of these circumvention activities is that the postcolonial state is encountering growing pressures from the business sector and facing a serious erosion of its role as the arbitrator of class interests.

The growing tendency of the business sector to influence local politics by directly lobbying mainland officials is reflected by the large number of business delegations organized to visit Beijing. Table 4 summarizes the number of Hong Kong delegations to Beijing from 1998 to 2011. The business sector has organized nearly 40 per cent of the total number of delegations. Table 5 illustrates that during their visits to Beijing, Hong Kong's capitalists were received by senior Beijing officials, including state leaders, NPC and CPPCC officials and other senior ministers. While it has not been possible to trace the behind-the-scene discussions between the business elites and Beijing officials and those visits that were not publicly organized, the statistics indicate that Hong Kong's business people are eager to engage with and lobby the Beijing authorities directly.

Table 6 provides more concrete examples to illustrate how the governing authority and autonomy of the post-colonial state are being eroded by the circumvention activities of the business sector, including cases like housing targets, the single development approach for West Kowloon Cultural Development Project and the extension of the "black out period" for listed company directors. This table is definitely far from being exhaustive as it only includes those highprofile circumvention activities reported by the media. However, it provides a useful snapshot of how Hong Kong's capitalists establish unprecedented power leverage vis-à-vis the post-colonial state through their political and economic access to the mainland authorities. As the business sector's circumvention activities become a normal part of post-1997 political life, the post-colonial state struggles to maintain its effective governance and uphold its authority as the ultimate power holder in the territory. 
Table 4: Hong Kong Delegations to Beijing (1998-2011)

\begin{tabular}{|c|c|c|c|c|c|c|c|c|c|c|c|c|c|c|c|}
\hline Delegations by background & 1998 & 1999 & 2000 & 2001 & 2002 & 2003 & 2004 & 2005 & 2006 & 2007 & 2008 & 2009 & 2010 & 2011 & Total \\
\hline Business organizations & 9 & 4 & 10 & 9 & 4 & 9 & 6 & 6 & 5 & 5 & 4 & 9 & 3 & 13 & 96 \\
\hline Charities bodies & 3 & 2 & 4 & 2 & 3 & 4 & 3 & 6 & 3 & 1 & 2 & 3 & 2 & 2 & 40 \\
\hline Professional bodies & 2 & 2 & 2 & 7 & 2 & 2 & 1 & 2 & 1 & 0 & 0 & 2 & 3 & 3 & 29 \\
\hline Townsmen associations & 0 & 1 & 0 & 2 & 2 & 0 & 4 & 4 & 1 & 0 & 0 & 1 & 2 & 3 & 20 \\
\hline Political parties/political groups & 0 & 0 & 2 & 0 & 0 & 4 & 2 & 0 & 3 & 2 & 3 & 0 & 0 & 2 & 18 \\
\hline District bodies & 0 & 1 & 2 & 1 & 0 & 2 & 1 & 1 & 0 & 0 & 1 & 0 & 2 & 1 & 12 \\
\hline Women's associations & 1 & 0 & 0 & 1 & 2 & 2 & 0 & 0 & 0 & 1 & 0 & 2 & 0 & 0 & 9 \\
\hline Cultural bodies & 3 & 0 & 0 & 1 & 0 & 2 & 0 & 0 & 1 & 0 & 0 & 0 & 0 & 0 & 7 \\
\hline Youth associations & 2 & 0 & 0 & 0 & 0 & 0 & 0 & 0 & 0 & 0 & 0 & 0 & 0 & 5 & 7 \\
\hline Religious bodies & 2 & 1 & 0 & 0 & 0 & 0 & 0 & 0 & 0 & 1 & 0 & 0 & 0 & 0 & 4 \\
\hline Others & 0 & 3 & 3 & 1 & 0 & 2 & 1 & 0 & 0 & 0 & 0 & 0 & 0 & 3 & 13 \\
\hline Total & 22 & 14 & 23 & 24 & 13 & 27 & 18 & 19 & 14 & 10 & 10 & 17 & 12 & 32 & 255 \\
\hline
\end{tabular}

Source:

Author's own research based on the content analysis of reports in four Hong Kong newspapers: Ming Pao, Hong Kong Economic Journal, Ta Kung Po and Wen Wei Po. The content analysis was conducted using the keywords "Fang Jing Tuan" through the WiseNews electronic platform. 
Table 5: State Officials Visited by Business Delegations (1997-2011)

\begin{tabular}{lrr}
\hline & No. ${ }^{*}$ & \multicolumn{1}{c}{$\%$} \\
State leaders & 30 & 10.7 \\
$\quad$ (president, vice-president, premier and vice-premier) & 1 & 0.4 \\
Officials from NPC & 15 & 5.4 \\
Officials from National Committee of CPPCC & 44 & 15.7 \\
Officials from Hong Kong and Macau Affairs Office of the State Council & 146 & 52.1 \\
Officials of other State Council ministries and commissions & 43 & 15.4 \\
United Front Work Department & 1 & 0.4 \\
Others & 280 & 100 \\
Total & & \\
Note: & ${ }^{*}$ refers to the number of Hong Kong delegations received by state officials. As a delegation may be received by more than one state \\
official, the total number here is not the same as the total of number of business delegations in Table 8. & &
\end{tabular}

\section{Prospects for the Partnership in the Aftermath of the 2012 Chief Executive Election}

The partnership between Beijing and Hong Kong's capitalists has been a significant factor shaping the first 15 years of HKSAR governance and has resulted in growing cleavages within the post-handover state-business alliance. However, the realpolitik concerning the 2012 chief executive election has raised new questions about the future of such a partnership.

The 2012 chief executive election was the most controversial leadership contest in the history of Hong Kong. It was a three-way race with the two pro-establishment candidates, Henry Tang Ying-yen 唐英年 and Leung Chun-ying 梁振英, standing against each other, and Albert Ho Chun-yan 何俊仁 from the prodemocracy camp. ${ }^{51}$ The result of the election, held on 25 March 2012, was a "divisive poll": the 1,200-member chief executive election committee gave Leung Chun-ying 689 votes, Tang Ying-yen 285 votes, Ho Chun-yan 76 votes, and 82 papers were declared invalid. ${ }^{52}$

Leung Chun-ying's electoral victory was a surprise to many people. At the beginning of the electoral contest, Tang was widely considered as the forerunner for the post, having been groomed by the Chinese government for decades. ${ }^{53}$ Tang was also seen as the candidate favoured by the major business tycoons ${ }^{54}$ and commanded much stronger business support than Leung (see Table 7 for the background analysis of candidates). Thus, when Beijing took the unprecedented

51 "It's a three-way race," The Standard, 1 March 2012.

52 "Leung seeks unity after divisive poll," South China Morning Post, 26 March 2012.

53 As a businessman-turned-politician, Henry Tang was groomed by Beijing for the chief executive position for decades. The Chinese government appointed him as secretary for commerce, industry and technology in 2002, financial secretary in 2003, and chief secretary for administration in 2007. Henry Tang's father, Tang Hsiang-chien, a textile industrialist from Shanghai, developed ties with former Chinese president Jiang Zemin and Henry Tang's election bid was seen as supported by the Shanghai faction.

54 Leung, Sophie. 2011. "China's Hong Kong succession takes shape as Tang steps down," 28 September, http://www.bloomberg.com/news/2011-09-28/hong-kong-chief-secretary-henry-tang-said-to-resign-anno uncement-planned.html. 


\section{Policy initiative \\ 85,000 housing targets}

Single development approach for West

Kowloon Cultural

Development Project

Extension of the "blackout period" for listed company directors
Year Dissatisfaction of business sector

2000 Property prices dropped by over 50\% after the implementation of a policy to construct 85,000 public housing apartments annually by the Tung Chee-hwa administration in 1997.

Property tycoons wanted the HKSAR government to change its public housing programme which they considered seriously affected their interests.

2004 The HKSAR government proposed to adopt a single development approach under which a single tender would be awarded to develop the entire 40-hectare West Kowloon site. Many property developers complained that such an approach would only benefit the biggest developers.

2009 The business sector strongly opposed the Hong Kong Stock Exchange's proposal to extend the blackout period for listed company directors from one month to seven months.

Notes:

${ }^{1}$ Goodstadt 2009, 136; ${ }^{2}$ Hong Kong Economic Times 2000; ${ }^{3}$ Ming Pao 2004; ${ }^{4}$ Ming Pao 2009.

\section{Circumvention tactic}

Property tycoons used their political connections to take their complaints to Beijing leaders. ${ }^{1}$ It was reported that some tycoons had expressed their concerns about Hong Kong's property market to state leaders during a visit to Beijing in June $2000 .^{2}$

It was reported that many property developers complained to the mainland authorities that the single development approach was unfair and requested that the lot be broken up into small pieces of land for public tender so that small and medium developers could participate in the project. $^{3}$

It was reported that some business leaders had gone straight to the mainland authorities to complain. Ronnie Chan, chairman of Hang Lung Properties Ltd., publicly confirmed the existence of such circumvention activities. ${ }^{4}$

\section{Outcome}

Shortly after the property tycoons' visit to Beijing, chief executive Tung Chee-hwa announced that the target of constructing 85,000 apartments no longer existed.

In February 2006, the new Donald Tsang administration announced that the single development approach would be ditched and that a new round of public consultation for the whole project would take place.

In February 2009, the Hong Kong Stock Exchange modified its proposal and announced that the blackout period would only be extended from one month to three months. 
Table 7: Background Analysis of Leung Chun-ying and Henry Tang Ying-yen's Supporters

\begin{tabular}{lccrc}
\hline Occupational background & Leung Chun-ying & \multicolumn{2}{c}{$\begin{array}{c}\text { Henry Tang } \\
\text { Ying-yen }\end{array}$} \\
& No. & $\%$ & No. & $\%$ \\
Politician & 33 & 10.8 & 25 & 6.4 \\
Business & $\mathbf{9 2}$ & $\mathbf{3 0 . 2}$ & $\mathbf{2 7 8}$ & $\mathbf{7 1 . 3}$ \\
Professional & 64 & 21 & 35 & 9 \\
Social services & 32 & 10.5 & 24 & 6.2 \\
Labour & 21 & 6.9 & 1 & 0.3 \\
Culture \& media & 6 & 2 & 17 & 4.4 \\
Agriculture & 39 & 12.8 & 2 & 0.5 \\
Others & 18 & 5.9 & 8 & 2.1 \\
Total & 305 & 100 & 390 & 100
\end{tabular}

Source:

Author's own research based on the notice of nominations for the 2012 chief executive election and the membership list of 2011 Chief Executive Election Committee, available on the official website of Electoral Affairs Commission, www.eac.gov.hk. Notes:

See notes for Table 1 for definition of categories.

step of not running with the tycoons' preferred candidate, ${ }^{55}$ some commentators argued that the long-time partnership between Beijing and Hong Kong's capitalists had come to an end. ${ }^{56}$

Did the victory of the more populist Leung Chun-ying over business-oriented Henry Tang signal the end of the partnership between Beijing and Hong Kong's capitalists? It is a question of realpolitik rather than a question that can be satisfactorily answered by academic research at the time of writing. However, a closer examination of the political dynamics before and after the election would indicate that the partnership between Beijing and Hong Kong's capitalists is unlikely to change overnight and may continue to shape HKSAR governance in the years to come.

Beijing's final decision to handpick Leung Chun-ying instead of Henry Tang was a "Morton's Fork scenario," involving a choice between the lesser of the two evils, rather than a deliberately-designed plan to change its partnership with the Hong Kong capitalists. As the favourite candidate of the major business tycoons and the senior civil servants, it appears that it was Beijing's original intention to back Henry Tang as the next chief executive. ${ }^{57}$ Although Beijing

55 It was clear that the major business tycoons favoured Henry Tang and disliked Leung Chun-ying because Leung had advocated increasing land supply and bringing down property prices. When there were signs that Beijing was switching its support to Leung Chun-ying, business supporters of Henry Tang, including Jeffrey Lam Kin-fung of the Hong Kong General Chamber of Commerce and Philip Wong Yu-hong of the Chinese General Chamber of Commerce, warned that investors would withdraw their capital from Hong Kong if Leung was elected. On 16 March 2012, Hong Kong's richest tycoon, Li Ka-shing, even publicly voiced his support for Henry Tang. These remarks indicated the major business tycoons' strong disapproval of Beijing's decision to handpick Leung Chun-ying instead of Henry Tang as the next HKSAR chief executive.

56 See Wong 2012; Chan 2012.

57 "Beijing 'prefers Tang as new boss'," South China Morning Post, 20 September 2012. 
gave Leung Chun-ying the green light to enter the race in September 2011 to lend a competitive edge to the electoral process, ${ }^{58}$ Henry Tang was still seen as Beijing's first choice. However, Beijing was forced to revisit this plan after Tang became embroiled in an unauthorized building works scandal which dealt a severe blow to his popular support ratings and creditability. ${ }^{59}$ Under these circumstances, it was only politic for Beijing to shift its support away from the scandal-plagued Henry Tang for fear of invoking widespread public anger in Hong Kong. ${ }^{60}$ Given that Tang had already become an unelectable candidate and that scuttling the poll would create further uncertainties, ${ }^{61}$ the only option for the stability-obsessed leaders in Beijing was to throw their support behind Leung Chun-ying, who commanded a higher level of popular support in various opinion polls. ${ }^{62}$ At the same time, Beijing stepped up its efforts to pacify Henry Tang's supporters in the business sector. ${ }^{63}$ Seen from this perspective, it seems that Beijing, in making its final decision to back Leung instead of Tang, was opting for damage control rather than deliberately seeking to change its partnership with the local capitalists and its longstanding policy to govern Hong Kong through the state-business alliance. ${ }^{64}$

58 "Tang Leung Tong ru zha Zhongyang kai lu deng," (Central government gave green light to Tang and Leung's candidacies), Ming Pao, 24 September 2011, A10.

59 On 13 February 2012, Ming Pao reported that there was an unapproved basement extension at Henry Tang's home at No. 7 York Road, Kowloon Tong. Tang initially said that the unauthorized work was to his home at No. 5A York Road, and was for a canopy above the garage which required digging works to be carried out to deepen the garage for storage. However, on 15 February 2012, Sharp Daily released a set of floor plans indicating that the unauthorized structure was a 2,400-square-foot illegal basement comprising store room, fitness room, cinema and wine-tasting room. On 16 February 2012, Henry Tang's wife took responsibility for the unauthorized works and Tang apologized for mishandling the issue. The scandal seriously damaged the credibility of Henry Tang and opinion polls showed that the majority of respondents wanted Henry Tang to quit the chief executive race. See "Tang Ying-yen she yinman jianjian" (Henry Tang suspected of covering up unauthorized works), Ming Pao, 13 February 2012, A01; “Tang Ying-yen dixia xingong” (Henry Tang's new underground palace), Sharp Daily, 15 February 2012, A01.

60 "China frets as choice for Hong Kong leader strays off script," Reuters, 22 February 2012.

61 When Henry Tang became embroiled in the unauthorized building works scandal, some business elites argued that members of the election committee should cast a blank vote collectively so that neither Leung Chun-ying nor Henry Tang would have a clear majority to win. To do so would have forced a new round of campaigns in early May and would have provided enough room for the business sector to identify another, more credible, candidate to replace Henry Tang. However, the idea of scuttling the poll alarmed the leaders in Beijing who believed that it would only make it more difficult to control the electoral process and would be harmful for Hong Kong's stability. For details, see "Te shou xuanju chuxian liuxuan weiji" (The chief executive election may be aborted), Yazhou zhoukan, 11 March 2012, 28-29.

62 Throughout the election, Henry Tang was trailing Leung Chun-ying in various opinion polls and Leung's support ratings steadily stood above the 40 per cent line. For details, see the website of the Public Opinion Programme, University of Hong Kong at http://hkupop.hku.hk.

63 For example, in his meeting with the Hong Kong's NPC and CPPCC delegations on 9 March 2012, Wang Guangya emphasized that, regardless of who took up the office of chief executive, Hong Kong was still a capitalist economy and the interests of the business sector had to be protected while answering public demands. These remarks have been interpreted as a deliberate attempt by Beijing to pacify those who supported Tang. For details, see "Wang Guangya tan te shou xuanju" (Wang Guangya speaks on chief executive election), Wen Wei Po, 10 March 2012, 102.

64 Interview with a senior pro-Beijing politician, April 2012. 
Table 8: Background Analysis of Members of the 2012 Preparatory Committee for National Day Celebrations and HKSAR Personalities Meeting Chinese President Hu Jintao on 30 June 2012

\begin{tabular}{lrcrc}
\hline $\begin{array}{l}\text { Occupational } \\
\text { background }\end{array}$ & $\begin{array}{r}\text { 2012 Preparatory Committee } \\
\text { for National Day Celebrations }\end{array}$ & \multicolumn{2}{c}{$\begin{array}{c}\text { HKSAR personalities invited } \\
\text { to meet Chinese President Hu } \\
\text { Jintao }\end{array}$} \\
& \multicolumn{1}{c}{ No. } & $\%$ & No. & $\%$ \\
Government & 19 & 11.9 & 11 & 5.6 \\
Politician & 3 & 1.9 & 9 & 4.6 \\
Business & $\mathbf{8 3}$ & $\mathbf{5 2 . 2}$ & $\mathbf{9 1}$ & $\mathbf{4 6 . 7}$ \\
Professional & 8 & 5 & 24 & 12.3 \\
Social services & 25 & 15.7 & 36 & 18.5 \\
Labour & 5 & 3.1 & 3 & 1.5 \\
Culture \& media & 13 & 8.2 & 19 & 9.7 \\
Others & 3 & 1.9 & 2 & 1 \\
Total & $159 *$ & 100 & 195 & 100
\end{tabular}

Source:

Author's own research based on the membership list of the Presidium of Preparatory Committee for National Day Celebrations, available in Ta Kung Po and Wen Wei Po, and the list of HKSAR personalities who were invited to meet Hu Jintao on 30 June 2012, obtained from the Chief Executive's Office in July 2012.

Notes:

See notes for Table 1.

Second, post-election developments indicate that Beijing has made every effort to mend its partnership with Hong Kong's capitalists, and the business sector remains the dominant player in its united front work. Following on from the election, Beijing's leaders have made "grand reconciliation" (da hejie 大和解) the theme of Hong Kong policy and have repeatedly called for unity within the pro-establishment camp. ${ }^{65}$ In line with the spirit of Beijing's policy, Leung Chun-ying embarked on a series of courtesy meetings with leading business figures. ${ }^{66}$ More importantly, the local capitalists, as in the past few decades, remain the principal target of Beijing's political co-option. As indicated from the membership list of the 2012 Preparatory Committee for National Day Celebrations and the list of HKSAR personalities who were invited to meet Chinese president, Hu Jintao, during his visit to Hong Kong on 30 June 2012 (Tables 8 and 9), big business tycoons and leaders of major business associations are still the dominant players in Beijing's united front.

In view of the above, there is no corroborative evidence that the 2012 chief executive election represented an important change in the longstanding

65 For example, the director of the Hong Kong and Macau Affairs Office, Wang Guangya, in his meeting with the chief executive-elect, Leung Chun-ying, on 9 April 2012, said that after the election different factions should put aside their differences and pursue reconciliation and unity.

66 After the election, Leung Chun-ying held high-profile meetings with leading business figures and major business associations (such as the Hong Kong General Chamber of Commerce, the Chinese General Chamber of Commerce, the Chinese Manufacturers' Association of Hong Kong and the Federation of Hong Kong Industries) on 2 April 2012. On 30 May 2012, Leung also paid a courtesy visit to Li Ka-shing and had lunch with him in his office in the Cheung Kong Centre. 
Table 9: Business Tycoons and Leaders of Major Business Associations in Beijing's United Front

\begin{tabular}{|c|c|c|c|}
\hline Name & Affiliation & $\begin{array}{l}2012 \text { Preparatory } \\
\text { Committee for } \\
\text { National Day } \\
\text { Celebrations }\end{array}$ & $\begin{array}{l}\text { HKSAR Personalities } \\
\text { Meeting Chinese } \\
\text { President Hu Jintao } \\
\text { on } 30 \text { June } 2012\end{array}$ \\
\hline Li Ka-shing & $\begin{array}{l}\text { Chairman of Cheung } \\
\text { Kong Holdings } \\
\text { Limited }\end{array}$ & $\mathrm{X}^{*}$ & $\mathrm{X}$ \\
\hline $\begin{array}{l}\text { Kwok } \\
\quad \text { Ping-sheung }\end{array}$ & $\begin{array}{l}\text { Non-executive director } \\
\text { of Sun Hung Kai } \\
\text { Properties Limited }\end{array}$ & $\mathrm{X}$ & $\mathrm{X}$ \\
\hline Lee Shau-kee & $\begin{array}{l}\text { Chairman of } \\
\text { Henderson Land } \\
\text { Development } \\
\text { Company Limited }\end{array}$ & $\mathrm{X}$ & $\mathrm{X}$ \\
\hline Cheng Yu-tung & $\begin{array}{l}\text { Founder of the New } \\
\text { World Development } \\
\text { Company Limited }\end{array}$ & $\mathrm{X}$ & $\mathrm{X}$ \\
\hline $\begin{array}{l}\text { Woo } \\
\text { Kwong-ching }\end{array}$ & $\begin{array}{l}\text { Chairman of the Wharf } \\
\text { Holdings Limited }\end{array}$ & $\mathrm{X}$ & $\mathrm{X}$ \\
\hline Chan Chi-chung & $\begin{array}{l}\text { Chairman of Hang } \\
\text { Lung Group Limited }\end{array}$ & $\mathrm{X}$ & $\mathrm{X}$ \\
\hline Li Kwok-po & $\begin{array}{l}\text { Chairman of the Bank } \\
\text { of East Asia }\end{array}$ & $\mathrm{X}$ & $\mathrm{X}$ \\
\hline Ho Tsu-kwok & $\begin{array}{l}\text { Chairman of Hong } \\
\text { Kong Tobacco } \\
\text { Company Limited }\end{array}$ & $\mathrm{X}$ & $\mathrm{X}$ \\
\hline Ho Hung-sun & $\begin{array}{l}\text { Chairman of the Shun } \\
\text { Tak Group }\end{array}$ & $\mathrm{X}$ & $\mathrm{X}^{*}$ \\
\hline Lui Che-woo & $\begin{array}{l}\text { Chairman of K. Wah } \\
\text { Group }\end{array}$ & $\mathrm{X}$ & $\mathrm{X}$ \\
\hline $\begin{array}{l}\text { Chow } \\
\text { Chung-kwong }\end{array}$ & $\begin{array}{l}\text { Chairman of Hong } \\
\text { Kong General } \\
\text { Chamber of } \\
\text { Commerce }\end{array}$ & $\mathrm{X}$ & $\mathrm{X}$ \\
\hline $\begin{array}{l}\text { Choi } \\
\text { Koon-shum }\end{array}$ & $\begin{array}{l}\text { Chairman of Chinese } \\
\text { General Chamber of } \\
\text { Commerce }\end{array}$ & $\mathrm{X}$ & $\mathrm{X}$ \\
\hline Irons Sze & $\begin{array}{l}\text { President of Chinese } \\
\text { Manufacturers' } \\
\text { Association of Hong } \\
\text { Kong }\end{array}$ & $\mathrm{X}$ & $\mathrm{X}$ \\
\hline Zhong Zhi-ping & $\begin{array}{l}\text { Chairman of } \\
\text { Federation of Hong } \\
\text { Kong Industries }\end{array}$ & $\mathrm{X}$ & $\mathrm{X}$ \\
\hline
\end{tabular}


partnership between the Chinese government and the Hong Kong's capitalist class. At the time of writing, maintaining a partnership with the business sector is still at the very core of Beijing's policy towards Hong Kong. Given that the PRC government and Hong Kong's capitalists still share many common interests, including maintaining the pre-existing HKSAR political-economic order and resisting the challenges of the democrats, there is no clear sign that Beijing will fundamentally change its policy in the foreseeable future. But, this does not mean that the partnership is completely static. In the years to come, possible transformations in the political and economic landscapes, such as the implementation of the timetable for universal suffrage in 2017, the further consolidation of pro-Beijing political parties and the growing influence of mainland capital, may bring about changes in the dynamics of the partnership. Nevertheless, how such a partnership will evolve in future and whether Hong Kong's capitalists will be able to maintain their positions of influence and power leverages remains a future research topic for political scientists.

\section{Conclusion}

Hong Kong has always been a dependent polity subject to the ultimate control of a more powerful sovereign state - London before 1997 and Beijing after 1997. ${ }^{67}$ Given its political status as a local polity, the relationship between the business sector and the sovereign state has strong implications for the autonomy of the Hong Kong state: a more distant relationship between the business sector and the sovereign state will help the Hong Kong state to uphold its governing authority, while a close partnership between the business sector and the sovereign state will undermine the authority of the Hong Kong state as the final arbitrator in the territory.

Unfortunately, the post-colonial state has been trapped in the latter situation. The business sector has become the major coalition partner of the sovereign state since the handover and Hong Kong's capitalists have gained privileged access to Beijing by virtue of their over-representation in the NPC and CPPCC delegations, their close relationship with the Liaison Office and intricate business networks with mainland authorities. Although these rules of engagement were deliberately designed by Beijing to perpetuate the state-business alliance after 1997, the ultimate irony is that they have allowed the business sector to establish direct access to the sovereign state and have equipped them with unprecedented power leverages vis-à-vis the post-colonial state, changing the play of politics in Hong Kong. Whether and how this partnership evolves after the 2012 chief executive election remains to be seen. 


\section{References}

Cao, Erbao. 2008. "'Yiguo liangzhi' tiaojianxia Xianggang de guanzhi liliang” (Governing force in Hong Kong under "one country, two systems"), Xuexi shibao, 28 January.

Chan, King-cheung. 2012. "Cong jintian qi, renren dou chengliao minzhu pai" (Starting from today, everyone becomes a democrat), 26 March, http://www.hkej.com/template/forum/php/forum details.php?blog_posts_id=83037. Assessed 27 March 2012.

Cheung, Anthony, and Paul C. W. Wong. 2004. "Who advised the Hong Kong government? The politics of absorption before and after 1997." Asian Survey 44(6), 874-894.

Dillion, Michael. 2009. Contemporary China: An Introduction. New York: Routledge.

Feng, Bangyan. 1996. Xianggang Ying zicai tuan: 1841-1996 (British Capital in Hong Kong). Hong Kong: Joint Publishing (H.K.).

Goodstadt, Leo F. 2000. "China and the selection of Hong Kong's post-colonial political elite." The China Quarterly 163, 721-741.

Goodstadt, Leo F. 2009. Uneasy Partners: the Conflict between Public Interest and Private Profit in Hong Kong. Hong Kong: Hong Kong University Press.

Hong Kong Economic Times. 2000. "Jugu fang Jing: Ng Chee-siong nitan loushi” (Business tycoons to visit Beijing: Ng Chee-siong plans to express concerns on property market), 23 June.

Huang, Yasheng. 1997. "The economic and political integration of Hong Kong: implications for government-business relations." In Warren I. Cohen and Li Zhao (eds.), Hong Kong under Chinese Rule: the Economic and Political Implications of Reversion. Cambridge: Cambridge University Press, 96-113.

King, Yeo-chi Ambrose. 1991. The Hong Kong Talks and Hong Kong Politics. Hong Kong: Hong Kong Institute of Asia-Pacific Studies.

Kuan, Hsin-chi. 1991. "Power dependence and democratic transition: the case of Hong Kong." The China Quarterly 128, 774-793.

Lau, Siu-kai. 1994. "Hong Kong's 'ungovernability' in the twilight of colonial rule." In Zhiling Lin and Thomas W. Robinson (eds.), The Chinese and Their Future: Beijing, Taipei, and Hong Kong. Washington, DC: AEI Press, 287-314.

Loh, Christine. 2010. Underground Front: The Chinese Communist Party in Hong Kong. Hong Kong: Hong Kong University Press.

Ma, Ngok. 2007. Political Development in Hong Kong State: Political Society and Civil Society. Hong Kong: Hong Kong University Press.

Miliband, Ralph. 1969. The State in Capitalist Society. New York: Basic Books.

Miners, Norman. 1987. Hong Kong under Imperial Rule, 1912-1941. Hong Kong: Oxford University Press

Miners, Norman. 1998. The Government and Politics of Hong Kong (5th ed). Hong Kong: Oxford University Press.

Ming Pao. 2004. "Shangjie gao yuzhuang hong xijiu zhaobiao bugong" (The business sector complained to Beijing that the single development approach was unfair), 27 November.

Ming Pao. 2009. "Chan Chi-chung baoliao jinshouji youren gao yuzhuang" (Ronnie Chan said some people protested the extension of black out period to Beijing), 11 February.

Ngo, Tak-wing. 2000a. "Changing government-business relations and the governance of Hong Kong." In Robert F. Ash (ed.), Hong Kong in Transition: the Handover Years. New York: St. Martin's Press, 26-41.

Ngo, Tak-wing. 2000b. "Business strategy, state intervention, and regionalization in East Asia." In Menno Vellinga (ed.), The Dialectics of Globalization: Regional Responses to World Economic Processes: Asia, Europe, and Latin America in Comparative Perspective. Boulder, CO: Westview Press, 83-99.

Qu, Baozhi. 2007. "Mainland China-Hong Kong Economic relations.” In Yeung Yue-man (ed.), The First Decade: The Hong Kong SAR in Retrospective and Introspective Perspectives. Hong Kong: Chinese University Press, 383-419. 
Poulantzas, Nicos Ar. 1978. Political Power and Social Classes. London: Verso.

Rear, John. 1971. "One brand of politics.” In Keith Hopkins (ed.), Hong Kong: The Industrial Colony: A Political, Social and Economic Survey. Hong Kong: Oxford University Press, 55-139.

Scott, Ian. 1989. Political Change and the Crisis of Legitimacy in Hong Kong. Hong Kong: Oxford University Press.

Slater, Dan. 2010. Ordering Power: Contentious Politics and Authoritarian Leviathans in Southeast Asia. Cambridge: Cambridge University Press.

So, Alvin Y. 1999. Hong Kong's Embattled Democracy: A Societal Analysis. Baltimore: Johns Hopkins University Press.

Tsang, Steve. 1997. Hong Kong: Appointment with China. New York: I.B. Tauris.

Wang, Tao, and Hong Liang. 2004. "Economic integration between Hong Kong SAR and mainland China.” In Eswar Prasad (ed.), Hong Kong SAR: Meeting the Challenges of Integration with the Mainland. International Monetary Fund Occasional Paper 226, 3-10.

Wong, Wai-lun. 2012. "Jianzhi zhongyang bu kekao, shang jie zenme ban?" (The central authority is no longer reliable, what should the business sector do?), Hong Kong Economic Times, 26 March, A38.

Xu, Jiatun. 1993. Xu Jiatun Xianggang huiyilu (Xu Jiatun's Memoirs). Taipei: Lianhebao.

Yep, Ray. 2007. "Links with the mainland.” In Lam Wai-man, Percy Luen-tim Lui, Wilson Wong and Ian Holiday (eds.), Contemporary Hong Kong Politics: Governance in the Post-1997 Era. Hong Kong: Hong Kong University Press, 245-264.

Yep, Ray. 2009. "Accommodating business interests in China and Hong Kong: two systems, one way out.” In Ka Ho Mok and Ray Forrest (eds.), Changing Governance and Public Policy in East Asia. New York: Routledge, 185-205.

Yep, Ray. 2010. "One country, two systems and special administrative regions: the case of Hong Kong." In Jae Ho Chung and Tao-chiu Lam (eds.), China's Local Administration: Traditions and Changes in the Sub-National Hierarchy. New York: Routledge, 86-109. 